\title{
แل Griffith
}

\section{Public Interest Disclosure Policy}

\begin{tabular}{|c|c|}
\hline Approving authority & Vice Chancellor \\
\hline Approval date & 16 October 2018 \\
\hline Advisor & $\begin{array}{l}\text { Peter Bryant | Vice President (Corporate Services) } \\
\text { vpcorporateservices@griffith.edu.au | (07) } 37357343\end{array}$ \\
\hline Next scheduled review & 2020 \\
\hline Document URL & http://policies.griffith.edu.au/pdf/Public Interest Disclosure Policy.pdf \\
\hline TRIM document & $2018 / 0000051$ \\
\hline Description & $\begin{array}{l}\text { This policy outlines the process, protections available and actions to be taken } \\
\text { as a result of a public interest disclosure being made. The policy has been } \\
\text { prepared to comply with section } 28 \text { of the Public Interest Disclosure Act } 2010 \\
\text { (QLD) ('the PID Act') which stipulates that the "chief executive officer of a } \\
\text { public sector entity" must establish reasonable procedures to deal with public } \\
\text { interest disclosures. The development of this policy was guided by the Model } \\
\text { Public Interest Disclosure Procedure developed by the Office of the } \\
\text { Queensland Ombudsman, as the oversight agency under the PID Act. }\end{array}$ \\
\hline
\end{tabular}

Related documents

Code of Conduct

Fraud Control Policy

Health and Safety Policy

Individual Grievance Resolution Procedure

Reporting and Resolution of Staff Sexual Assault Harassment Bullying and Discrimination Procedures

Staff Harassment, Bullying and Discrimination Policy

Student Complaints Policy

Student Complaints Procedures

Student Sexual Assault, Harassment, Bullying and Discrimination Policy

Procedures for Reporting and Responding to Student Sexual Assault, Harassment, Bullying and

Discrimination

Records Management Policy

External Links

Crime and Corruption Act 2001

Griffith University Act

Public Interest Disclosure Act 2010

Public Records Act 2002

Public Sector Ethics Act 1994

Queensland Ombudsman - Public Interest Disclosure Guides for Individuals Working in the Public Sector; Public Sector Managers and Supervisors; and Public Sector Organisations

[Introduction] [Scope] [A Public Interest Disclosure] [Making a Disclosure] [Receiving a Disclosure] [Assessment of a Disclosure] [Investigation of a Disclosure] [Organisational Support for Disclosers] [Rights of Officers who are Subject of a Disclosure] [Confidentiality] [Reprisals] Record Keeping and Reporting] [Definitions] 


\section{INTRODUCTION}

The University is committed to fostering an ethical, transparent culture and values the disclosure of information about suspected unlawful, negligent or improper conduct or about danger to public health or safety of the environment.

As a public sector entity established by an Act of the Queensland Parliament, Griffith University is covered by the Public Interest Disclosure Act 2010 (QId) ('the PID Act') and all University staff are public officers for the purposes of the legislation. The PID Act provides for the protection of staff of the University and, where applicable, other people making public interest disclosures (PIDs).

Staff can be the most important sources of information to assist the University to identify and address suspected wrongdoing.

The University supports the disclosure of information about suspected wrongdoing as this contributes to the organisation's integrity, assists in the prevention of fraud and other economic loss and ensures the trust of the community that the University serves.

PIDs and disclosers will be managed in accordance with the PID Act and with the standards issued by the Queensland Ombudsman under Section 60 of the PID Act. By complying with the PID Act, the University demonstrates its commitment to:

- Ensuring that all Public Interest Disclosures (PIDs) about suspected wrongdoing are properly assessed, appropriately investigated and that appropriate action is taken in relation to any wrongdoing.

- Providing support to an employee or others who make disclosures about matters in the public interest.

- Ensuring appropriate consideration is given to the interests of persons who are the subject of a PID.

- Ensuring protection from reprisal is afforded to persons making PIDs.

The Vice Chancellor, as chief executive officer, has overall responsibility under the PID Act for the University's compliance with the Act.

The Vice President (Corporate Services) (email: vpcorporateservices@griffith.edu.au | telephone (07 37357343 has been appointed the responsible officer for receiving disclosures and acting on them.

\section{SCOPE}

All University staff, whether they are continuing, fixed-term, temporary or casual appointments, including senior management, executive, academic, general, conjoint appointments, and members of the University Council and its committees are considered public officers for the purpose of this legislation.

\section{A PUBLIC INTEREST DISCLOSURE}

The PID Act distinguishes between public interest disclosures (PIDs) made by public officers and those made by others.

A public officer (including University staff) may make a PID about:

- Corrupt conduct as defined in Section 15 of the Crime and Corruption Act 2001 (refer to Section 13 Definitions).

- Maladministration that adversely affects anyone's interests in a substantial or specific way.

- Substantial misuse of public resources (other than an alleged misuse based on mere disagreement over policy).

- Substantial and specific danger to public health or safety. 
- Substantial and specific danger to the environment.

Any person (including former staff and public officers) may make a PID about:

- A substantial and specific danger to the health or safety of a person with a disability;

- A substantial and specific danger to the environment; or

- A reprisal taken against anybody as a result of a PID.

A disclosure amounts to a PID and is covered by the PID Act even if the

- Discloser reports the information as part of their duties;

- Disclosure is made anonymously - the discloser is not required to give their name or any identifying information;

- Discloser has not identified the material as a PID. The University must assess the information received and decide if it is a PID;

- Disclosure is unsubstantiated following investigation. The discloser is protected when the information they provide is assessed as a PID, whether or not it is subsequently investigated or found to be unsubstantiated.

University staff are encouraged to report wrongdoing and to seek assistance when doing so (refer to Section 4 Making a Disclosure).

\section{MAKING A DISCLOSURE}

All staff are required to comply with University policy, including the Code of Conduct which sets out the standards of behaviour expected of staff. Staff members who are aware of any activity or incident that they consider is wrongdoing or which would adversely impact on the operation of the University are encouraged to report the behaviour. However for disclosures to receive the unique protection of the PID Act it must concern corrupt conduct; maladministration; a misuse of public resources; danger to public health or safety; danger to the health or safety of a person with a disability; danger to the environment; or a reprisal (as detailed in Section 3 of this policy). Mere disagreements over policy do not meet the threshold for a PID under the PID Act.

A person who makes a PID is not subject to any civil or criminal liability or any liability arising by way of administrative process, including disciplinary action for making the disclosure. However it is an offence under the PID Act to intentionally give false or misleading information intending that it be acted on as a PID. Employees may be subject to disciplinary action for intentionally giving false or misleading information in a PID or during an investigation into a PID. While disclosers cannot be disciplined for making a PID, they continue to be subject to reasonable management action (see Section 13 Definitions).

An appropriate disclosure is where the:

- Discloser honestly and reasonably believes the information provided tends to show the conduct or danger;

- Information tends to show the conduct or danger regardless of the discloser's belief. Information that 'tends to show' wrongdoing or danger must be more than a mere suspicion. There must be information that indicates or supports a view that the wrongdoing or danger has or will occur.

The discloser is not required to undertake any investigative action before making a PID.

\subsection{Proper Authority}

Disclosers are protected under the PID Act only if PIDs are made to a proper authority as specified in the PID Act. The University is a proper authority for conduct concerning the University, a University employee or behaviour that the University has the power to investigate or remedy. Such PIDs may also be made to an external public sector agency having investigative powers in relation to particular matters (see Section 4.3 of this policy).

Should a disclosure be made other than to a proper authority, a member of the Legislative Assembly or an organisation that can investigate and deal with the matter, the discloser will not receive the protections provided under the PID Act (save as described in Section 4.4 of this policy). 


\subsection{Making a Disclosure to the University}

Wherever possible, a PID about the University should first be made internally so that the University has an opportunity to investigate the matter. This is usually the quickest and most effective way to correct wrongdoing and the option that best protects the discloser from reprisal.

Options for making a disclosure to the University include:

- An independent hotline 'Your Call' has been engaged by the University to impartially and confidentially manage disclosures, and to facilitate disclosers to provide information or concerns without fear of reprisal. Your Call will record the details of the PID, will refer the disclosure to the University and will act as an intermediary, including receiving and forwarding all communications between the discloser and the University. The University is responsible for all decisions and actions taken in response to a PID submitted via Your Call.

\section{Your Call contact information:}

The Your Call organisational identification code for the University is GRIFFITH.

Telephone Your Call on: 1300790228 on business days between 9.00 am and 12 am

Visit the Your Call website: www.yourcall.com.au/report to make a secure report online at any time using the organisational identification code: GRIFFITH. Your Call will provide disclosers with a disclosure identification number and password to enable subsequent communication via the Your Call message board.

For disclosers with a hearing or speech impairment, please contact the National Relay Service www.relayservice.gov.au and request Your Call's hotline.

Disclosers may opt to remain anonymous or to identify themselves to Your Call only, or to identify themselves to both Your Call and to the University.

The Vice President (Corporate Services) will have access to reports made by disclosers to Your Call and will assess the information received and decide if it is a PID. If the disclosure is about the Vice President (Corporate Services), the Vice Chancellor will have access to the report and will decide if it is a PID.

- Alternatively, disclosers may

Submit a verbal or written PID to:

- Your supervisor or other University officer who indirectly supervises or manages you;

- The Vice President (Corporate Services)

Email: vpcorporateservices@griffith.edu.au | Telephone (07) 373 57343;

- The Director, Audit, Risk and Compliance

Email d.raniga@griffith.edu.au | Telephone (07) 373 58513;

- The Manager, Internal Audit

Email d.constantinous@griffith.edu.au | Telephone (07) 373 56402;

- The Vice Chancellor, in the case of a disclosure about the Vice President (Corporate Services)

Email vc@griffith.edu.au | Telephone (07) 555 28178; or

- The Chancellor, in the case of a disclosure about the Vice Chancellor

Email chancellor@griffith.edu.au | Telephone (07) 37358502

The Act provides that a PID may also be made to:

- The Vice Chancellor;

- A member of University Council.

Disclosers are encouraged to provide their contact details when making a PID as this will enable the University to formally acknowledge the disclosure, make contact to ask for additional information if required, and to provide organisational support (as detailed in Section 8 of this policy). 


\subsection{Making an External Disclosure}

The discloser may choose to make a disclosure to someone external to the organisation because they are not satisfied with the University's response to a disclosure; or they are concerned about confidentiality. While staff are encouraged to make a disclosure to the University as a first step (as detailed in Section 4.2), disclosers will be respected and supported should they disclose to an external authority. It is very likely that the external authority will discuss the disclosure with the University and the University will make every effort to assist and cooperate with any external authority to work towards a satisfactory outcome.

External agencies that can receive PIDs are listed below:

- Crime and Corruption Commission (CCC) for disclosures about corrupt conduct including reprisal;

- Queensland Ombudsman for disclosure about maladministration;

- Queensland Audit Office for disclosures about a substantial misuse of resources;

- Department of Child Safety, Youth and Women for disclosures about danger to the health and safety of a child or young person with a disability;

- Department of Communities, Disability Services and Seniors or the Office of the Public Guardian for disclosures about danger to the health and safety of a person with a disability;

- Department of Environment and Science for disclosures about danger to the environment;

- A Member of the Legislative Assembly (MP) for any wrongdoing or danger.

\subsection{Making a Disclosure to a Journalist}

A disclosure made to a journalist is protected under the PID Act if the following conditions have been met:

- A valid PID was initially made to a proper authority; and

- The proper authority:

- Decided not to investigate or deal with the disclosure; or

- Investigated the disclosure but did not recommend taking any action; or

- Failed to notify the discloser within six months of making the disclosure whether or not the disclosure was to be investigated or otherwise dealt with.

Staff making a PID to a journalist should be aware that journalists are not bound under the confidentiality provisions of Section 65 of the PID Act.

\subsection{What Information to Provide When Making a PID}

While there is no particular information that the discloser needs to provide, the content provided should be clear and factual and avoid speculation. Depending on the circumstances, the discloser should where possible provide information on:

- The nature of the wrongdoing;

- The name, job title and workplace address of the person the subject of the disclosure;

- When (dates and times) and where the wrongdoing occurred;

- Events surrounding the issue;

- If the discloser did anything in response to the wrongdoing;

- Others who also know about the wrongdoing and have allowed it to continue;

- If the discloser is concerned about possible reprisal as a result of making the disclosure;

- Names of others who may be able to support the disclosure or any other evidence to support the disclosure;

- Steps already taken by the discloser to report the matter internally should also be included, if relevant.

See the disclosure flowchart for a summary of the PID process (Diagram 1 on page 14). 


\section{RECEIVING A DISCLOSURE}

Where a supervisor or other University officer receives a verbal PID, they should encourage the discloser to put the details in writing. If the discloser is unable or unwilling to do so, the supervisor or other University officer should document the PID and ask the discloser to confirm the contents before signing it and referring it to the Vice President (Corporate Services) [or to the Vice Chancellor if the disclosure is about the Vice President (Corporate Services)].

If an anonymous telephone caller calls a University staff member rather than the Whistleblower Hotline, the University staff member receiving the disclosure should record the date, time and circumstances of the PID. It should then be forwarded to the Vice President (Corporate Services).

\section{ASSESSMENT OF A DISCLOSURE}

The Office of the Vice President (Corporate Services) is the University's central contact point for the receipt and assessment of all PIDs. All PIDs, including those that are made anonymously, will be assessed by the Vice President (Corporate Services) to determine if the:

- Disclosure concerns a matter about which a PID can be made, in accordance with the PID Act and this policy;

- Disclosure has been made to a proper authority under the PID Act and in accordance with the University's policy;

- Person making the disclosure is able to receive the protection of the PID Act.

If there is doubt about whether a disclosure is a PID, further information may be obtained to inform the decision. If doubt still remains, the Vice President (Corporate Services) will assume the disclosure is protected and manage it as if it is a PID.

Upon receiving the PID, the Vice President (Corporate Services) will make an assessment as to whether it is to be referred to an external public sector agency, such as the Crime and Corruption Commission, for review or investigation or whether the University is able to investigate the matter or deal with it in some other way. If the matter is to be referred to an agency, the referral will be made in accordance with legislative and other requirements including seeking consent from the discloser to forward the information to the proper authority, informing the discloser when the information has been forwarded, and undertaking a risk assessment to ensure there is not an unacceptable risk that a reprisal would happen before the referral is made.

If the matter is required to be investigated by the University, the Vice President (Corporate Services) will be responsible for the investigation which may be completed by an internal or external investigator, as appropriate. If choosing to appoint an external investigator, the Vice President (Corporate Services) will not do so without first consulting the discloser, unless required by other relevant legislation.

If a disclosure is referred to the University under the PID Act by another entity, acknowledgement will be made in accordance with legislative requirements.

\section{INVESTIGATION OF A DISCLOSURE}

If a decision is made to investigate a PID, this will be done with consideration for the:

- Principles of natural justice.

- Obligations under the PID Act to protect confidential information.

- Obligation under the PID Act to protect officers from reprisal.

- Interests of subject officers.

If as a result of investigation the information about wrongdoing provided in the PID is substantiated, appropriate action will be taken. 
Once the investigation has been completed, a report of the investigation will be provided to the Vice President (Corporate Services). The report may contain recommendations for further action. The Vice President (Corporate Services) will decide what further action (if any) will be taken on the disclosure.

The discloser will be informed of progress and of the outcome by the Vice President (Corporate Services). If a decision is made not to investigate or deal with a PID, the discloser will be provided with written reasons for that decision. Where reasonable, the report (or an edited extract of the report) will be provided.

The discloser may request a review of the decision taken on the disclosure via a formal request made to the Vice Chancellor within 28 days after receiving written reasons. The Vice Chancellor (or delegate) will review the matter and determine whether to confirm or overturn the decision and written reasons will be provided to the discloser together with advice about the right of external review by the Queensland Ombudsman.

\section{ORGANISATIONAL SUPPORT FOR DISCLOSERS}

Disclosers are encouraged to provide their contact details when making a PID as this will enable the University to formally acknowledge the disclosure, make contact to ask for additional information if required, and to provide organisational support (as detailed below).

The University will treat all PIDs appropriately and seriously, ensuring privacy and confidentiality (as far as possible) throughout the process. The University reassures staff who report wrongdoing, whether the information constitutes a PID under the PID Act or not that they will be supported and protected from possible reprisals. Disclosers cannot be disciplined for making a PID but disclosers will continue to be managed in accordance with normal, fair and reasonable practices during and after the handling of the PID (see reasonable management action under Section 13 Definitions).

It is an offence under the PID Act to intentionally give false or misleading information intending that it be acted on as a PID. Staff who intentionally give false or misleading information may be subject to disciplinary action.

Once the matter has been assessed as a PID, the Vice President (Corporate Services) will advise the discloser:

- That their information has been received and assessed as a PID;

- The action to be taken in relation to the disclosure;

- The likely timeframe involved;

- The name and contact details of the support officer who the discloser may contact for updates or advice. The support officer will have sufficient authority to ensure that the discloser has appropriate organisational support and protection from reprisals and will be separate from the investigation function;

- The discloser's obligations regarding confidentiality, except as allowed under the PID Act;

- The protections the discloser has under the PID Act;

- The commitment of the University to keep the discloser's identity and the information disclosed confidential, except where permitted under the PID Act;

- The discloser's likely involvement in any action to be taken and how updates regarding intended actions and outcomes will be provide to the discloser;

- The arrangements that will be put in place to support the discloser and contact details for the University's employee assistance program.

The Vice President (Corporate Services) will conduct a risk assessment to ensure that the health, safety and wellbeing of the discloser is not put at risk as a result of making the disclosure, and assess the likelihood of the discloser suffering reprisal action as a result of having made the disclosure. The assessment will take into account the actual and perceived risk of the discloser suffering detriment and will include consultation with the discloser and their consent to consult with other entities or third parties 
about the risk assessment, if required. The assessment of risk to the discloser and others associated with the discloser and the protective measures will be proportionate to the risk and potential consequences of any reprisal. The risk management plan developed in response to the assessment will be developed in consultation with the discloser and will be regularly reviewed and amended if required, until management of the PID is finalised. The Vice President (Corporate Services) will also consider the University's obligations to any officers who are the subject of the PID.

In undertaking the risk assessment and the development of the risk management plan, the Vice President (Corporate Services) will protect the confidentiality of the discloser and the PID information.

If the discloser is anonymous, the Vice President (Corporate Services) will conduct the risk assessment taking into account the information disclosed in the PID and any other information reasonably available.

The work environment of University affected staff will be monitored for any evidence of reprisal action. In the event of reprisal action being alleged or suspected, the University will:

- Attend to the safety of disclosers or affected third parties, including those who may wrongly be suspected of being a discloser, as a matter of priority;

- Review its risk assessment and risk management plan to mitigate any further risk of reprisal;

- Manage any allegation of a reprisal as a PID in accordance with the PID Act and provide support and information to the person reporting the alleged or suspected reprisal.

\section{RIGHTS OF OFFICERS WHO ARE SUBJECT OF A DISCLOSURE}

The University acknowledges that being the subject of a PID is a stressful experience. As the subject of an allegation, staff may seek assistance from a staff or legal representative or support person.

Those who are the subject of or in some way associated with a PID are entitled to confidentiality and the presumption of innocence and should not be treated adversely as a result of their involvement. The University will protect the rights of persons who are the subject of a PID by:

- Assuring them that the PID will be dealt with impartially, fairly and reasonably, in accordance with the principles of natural justice;

- Confirming that the PID is an allegation only until information or evidence obtained through an investigation substantiates the allegations;

- Providing them with information about their rights and the progress and outcome of any investigation;

- Referring them to the University's employee assistance program.

\section{CONFIDENTIALITY}

The University will, to the greatest extent possible, keep the disclosure and the identity of the discloser confidential. While all necessary steps will be taken to protect the confidentiality of the information provided, the discloser also has obligations to preserve confidentiality and not to discuss the disclosure with work colleagues or other unauthorised persons. It is an offence under Section 65 of the PID Act to make a record of or intentionally or recklessly disclose confidential information received in the administration of the PID Act, except as authorised under the PID Act.

Maintaining confidentiality protects the discloser against reprisals and also protects other people affected by the disclosure. In protecting confidentiality, the University will ensure that the details of the disclosure, the investigation and related decisions will be kept secure. Maintaining confidentiality encompasses:

- The fact that a disclosure has been made;

- Any information that may identify you or any person who may be the subject of a disclosure;

- The actual information that has been disclosed;

- Information relating to the disclosure that may cause detriment, if known. 
The University will attempt as far as possible to avoid a situation where the discloser's identity will need to be revealed. All statements and correspondence in relation to the matter will be regarded as strictly confidential.

While every attempt to protect confidentiality will be made, there will be occasions when disclosure of your identity will be unavoidable. These include:

- For procedural fairness (after considering the risk of reprisal).

- Responding to a court order or legal directive.

- In court proceedings.

- It is necessary to prevent a serious threat to a person's health or safety.

The University will advise the discloser if their identity may be revealed due to one of the reasons listed above, and the discloser's prior consent will be sought, if possible.

Where maintaining confidentiality is not possible or cannot be maintained, the University will consider on a case by case basis the steps to protect a discloser from reprisal.

\section{REPRISALS}

The PID Act provides that a person must not cause, or attempt to cause, detriment to another person because, or in the belief that, anybody has made, or may make, a PID. Such conduct is called a reprisal and is not condoned or tolerated by the University.

Furthermore, taking a reprisal action may also constitute corrupt conduct and be reported to the Crime and Corruption Commission.

Any information about reprisals, or suspected reprisals, at the University should be referred immediately to the Vice President (Corporate Services). Any such information is considered a PID and will be treated accordingly. (See Section 8 of this policy for further information about the process for assessing and managing the risks of reprisal).

\section{RECORD KEEPING AND REPORTING}

In accordance with its obligations under the PID Act and the Public Records Act 2002, the University will ensure that accurate data is collected about the receipt and management of all PIDs, and the deidentified data will be reported to the Office of the Queensland Ombudsman through the PID reporting database. The Queensland Ombudsman reports statistical information in the Office's annual report to the Parliament.

The Office of the Vice President (Corporate Services) will keep a secure record of all PIDs or purported PIDs received by the University in the central records system. Access to the confidential records will be strictly limited.

\section{DEFINITIONS}

\begin{tabular}{|l|l|}
\hline Term & Definition \\
\hline Chief Executive Officer & $\begin{array}{l}\text { The Vice Chancellor, as Chief Executive Officer of the University, } \\
\text { has overall responsibility under the PID Act for Griffith's compliance } \\
\text { with the Act including: }\end{array}$ \\
\hline & $\begin{array}{l}\text { - } \quad \text { Receiving PIDs } \\
\text { - } \quad \text { Keeping a record of disclosures }\end{array}$ \\
\hline
\end{tabular}




\begin{tabular}{|c|c|}
\hline & $\begin{array}{l}\text { - Reviewing the University's decisions not to investigate or deal } \\
\text { with PIDs on request } \\
\text { - Providing disclosure information to the Queensland } \\
\text { Ombudsman } \\
\text { - Delegating responsibilities under the PID Act as they consider } \\
\text { appropriate, and } \\
\text { Ensuring effective management and oversight of the } \\
\text { University's PID management program and procedures. } \\
\text { The Vice President (Corporate Services) (email: } \\
\text { vpcorporateservices@griffith.edu.au | telephone (0737357343 has } \\
\text { been appointed the responsible officer for receiving disclosures and } \\
\text { acting on them. }\end{array}$ \\
\hline Confidential information & $\begin{array}{l}\text { (a) includes: } \\
\text { (i) information about the identity, occupation, residential or } \\
\text { work address or whereabouts of a person - } \\
\text { (A) who makes a public interest disclosure; or } \\
\text { (B) against whom a public interest disclosure has been } \\
\text { made; and } \\
\text { (ii) information disclosed by a public interest disclosure; and } \\
\text { (iii) information about an individual's personal affairs; and } \\
\text { (iv) information that, if disclosed, may cause detriment to a } \\
\text { person; and } \\
\text { (b) Does not include information publicly disclosed in a public } \\
\text { interest disclosure made to a court, tribunal or other entity that } \\
\text { may receive evidence under oath, unless further disclosure of } \\
\text { the information is prohibited by law. }\end{array}$ \\
\hline Corrupt conduct & $\begin{array}{l}\text { As defined in section } 15 \text { of the Crime and Corruption Act 2001: } \\
\text { (1) Corrupt conduct means conduct of a person, regardless of } \\
\text { whether the person holds or held an appointment, that - } \\
\text { (a) adversely affects, or could adversely affect, directly or } \\
\text { indirectly, the performance of functions or the exercise of } \\
\text { powers of - } \\
\text { (i) a unit of public administration; or } \\
\text { (ii) a person holding an appointment; and } \\
\text { (b) results, or could result, directly or indirectly, in the } \\
\text { performance of functions or the exercise of powers } \\
\text { mentioned in paragraph (a) in a way that - } \\
\text { (i) } \quad \text { is not honest or is not impartial; or } \\
\text { (ii) involves a breach of the trust placed in a person } \\
\quad \text { holding an appointment, either knowingly or } \\
\quad \text { recklessly; or } \\
\text { involves a misuse of information or material } \\
\text { (iii) acquired in or in connection with the performance } \\
\quad \text { of functions or the exercise of powers of a person } \\
\text { holding an appointment; and } \\
\text { (c) is engaged in for the purpose of providing a benefit to the } \\
\text { person or another person or causing a detriment to another } \\
\text { person; and } \\
\text { (d) would, if proved be - } \\
\text { (i) a criminal offence; or } \\
\text { (e) A disciplinary breach providing reasonable grounds for } \\
\text { terminating the person's services, if the person is or were } \\
\text { the holder of an appointment. } \\
\text { (2) Without limiting subsection (1), conduct that involves any of the } \\
\text { following could be corrupt conduct under subsection (1) - } \\
\text { (a) abuse of public office; }\end{array}$ \\
\hline
\end{tabular}




\begin{tabular}{|c|c|}
\hline & $\begin{array}{l}\text { (b) bribery, including bribery relating to an election; } \\
\text { (c) extortion; } \\
\text { (d) obtaining or offering a secret commission; } \\
\text { (e) fraud; } \\
\text { (f) stealing; } \\
\text { (g) forgery; } \\
\text { (h) perverting the course of justice; } \\
\text { (i) an offence relating to an electoral donation; } \\
\text { (j) loss of revenue of the State; } \\
\text { (k) sedition; } \\
\text { (l) homicide, serious assault or assault occasioning bodily } \\
\text { (m) obtaining a financial benefit from procuring prostitution or } \\
\text { (n) illegal drug trafficking; } \\
\text { (o) illegal gambling. }\end{array}$ \\
\hline Detriment & $\begin{array}{l}\text { includes - } \\
\text { (a) personal injury or prejudice to safety; and } \\
\text { (b) property damage or loss; and } \\
\text { (c) intimidation or harassment; and } \\
\text { (d) adverse discrimination, disadvantage or adverse treatment } \\
\text { about career, profession, employment, trade or business; and } \\
\text { (e) financial loss; and } \\
\text { (f) damage to reputation, including for example, personal, } \\
\text { professional or business reputation. }\end{array}$ \\
\hline Disability & $\begin{array}{l}\text { As defined in section } 11 \text { of the Disability Services Act } 2006 \text {, for the } \\
\text { purposes of this procedure: } \\
\text { (1) a disability is a person's condition that - } \\
\text { (a) is attributable to - } \\
\text { (i) An intellectual, psychiatric, cognitive, neurological, } \\
\text { sensory or physical impairment; or } \\
\text { (ii) A combination of impairments mentioned in } \\
\text { subparagraph (i); and } \\
\text { (b) results in - } \\
\text { (2) For subsection (1), the impairment may result from an acquired } \\
\text { brain injury. } \\
\text { (3) The disability must be permanent or likely to be permanent. } \\
\text { (4) The disability may be, but need not be, of a chronic episodic } \\
\text { nature. }\end{array}$ \\
\hline Discloser & $\begin{array}{l}\text { A person who makes a disclosure in accordance with the Public } \\
\text { Interest Disclosure Act } 2010 .\end{array}$ \\
\hline Employee & $\begin{array}{l}\text { of an entity, includes a person engaged by the entity under a } \\
\text { contract of service. }\end{array}$ \\
\hline Journalist & $\begin{array}{l}\text { a person engaged in the occupation of writing or editing material } \\
\text { intended for publication in the print or electronic news media. }\end{array}$ \\
\hline Maladministration & $\begin{array}{l}\text { As defined in schedule } 4 \text { of the Public Interest Disclosure Act } 2010 \text {, } \\
\text { maladministration is administrative action that - } \\
\text { (a) was taken contrary to law; or } \\
\text { (b) was unreasonable, unjust, oppressive, or improperly } \\
\text { discriminatory; or } \\
\text { (c) was in accordance with a rule of law or a provision of an Act } \\
\text { or a practice that is or may be unreasonable, unjust, } \\
\text { oppressive, or improperly discriminatory in the particular } \\
\text { circumstances; or }\end{array}$ \\
\hline
\end{tabular}




\begin{tabular}{|c|c|}
\hline & $\begin{array}{l}\text { (d) was taken - } \\
\text { (i) for an improper purpose; or } \\
\text { (ii) on irrelevant grounds; or } \\
\text { (iii) having regard to irrelevant considerations; or } \\
\text { (e) was an action for which reasons should have been given, } \\
\text { but were not given; or } \\
\text { (f) was based wholly or partly on a mistake of law or fact; or } \\
\text { (g) was wrong. }\end{array}$ \\
\hline Natural justice & $\begin{array}{l}\text { Natural justice, also referred to as 'procedural fairness' applies to } \\
\text { any decision that can affect the rights, interests or expectations of } \\
\text { individuals in a direct or immediate way. Natural justice is at law a } \\
\text { safeguard applying to an individual whose rights or interests are } \\
\text { being affected. } \\
\text { The rules of natural justice, which have been developed to ensure } \\
\text { that decision-making is fair and reasonable, are: } \\
\text { - avoid bias; and give a fair hearing. } \\
\text { - act only on the basis of logically probative evidence. }\end{array}$ \\
\hline Organisational support & $\begin{array}{l}\text { For the purpose of this policy, organisational support means actions } \\
\text { such as, but not limited to: } \\
\text { - Providing moral and emotional support } \\
\text { - Advising disclosers about agency resources available to } \\
\text { handle any concerns they have as a result of making their } \\
\text { disclosure } \\
\text { - Appointing a mentor, confidante or other support officer to } \\
\text { assist the disclosure through the process } \\
\text { - Referring the discloser to the agency's Employee } \\
\text { Assistance Program or arranging for other professional } \\
\text { counselling } \\
\text { - Generating support for the discloser in their work unit where } \\
\text { appropriate } \\
\text { - Ensuring that the suspicions of victimisation or harassment } \\
\text { are dealt with } \\
\text { - Maintaining contact with the discloser } \\
\text { - Negotiating with the discloser and their support officer for } \\
\text { formal end to their involvement with the support program } \\
\text { when it is agreed that they no longer need assistance. }\end{array}$ \\
\hline PID Coordinator & $\begin{array}{l}\text { The Vice President (Corporate Services) } \\
\text { vpcorporateservices@griffith.edu.au | telephone }(0737357343 \text { has } \\
\text { been appointed the responsible officer for receiving disclosures and } \\
\text { acting on them. The Vice President (Corporate Services) is } \\
\text { responsible for implementation of the University's PID management } \\
\text { program, including acting as the principal point of contact with the } \\
\text { Queensland Ombudsman, as oversight agency. }\end{array}$ \\
\hline PID Support Officer & $\begin{array}{l}\text { A PID Support Officers is a suitably qualified member of the } \\
\text { University staff, delegated by the Vice President (Corporate } \\
\text { Services), as PID coordinator, with the responsibility for providing } \\
\text { support to a discloser, subject officer or witness who is involved in } \\
\text { the management of a PID. }\end{array}$ \\
\hline Proper authority & $\begin{array}{l}\text { A person or organisation that is authorised under the Public Interest } \\
\text { Disclosure Act } 2010 \text { to receive disclosures. }\end{array}$ \\
\hline Public officer & $\begin{array}{l}\text { A public officer, of a public sector entity, is an employee, member } \\
\text { or officer of the entity. }\end{array}$ \\
\hline Reasonable belief & A view which is objectively fair or sensible. \\
\hline
\end{tabular}




\begin{tabular}{|c|c|}
\hline $\begin{array}{l}\text { Reasonable management } \\
\text { action }\end{array}$ & $\begin{array}{l}\text { Action taken by a manager in relation to an employee, includes any } \\
\text { of the following taken by the manager - } \\
\text { (a) A reasonable appraisal of the employee's work performance; } \\
\text { (b) A reasonable requirement that the employee undertake } \\
\text { counselling; } \\
\text { (c) A reasonable suspension of the employee from the } \\
\text { employment workplace; } \\
\text { (d) A reasonable disciplinary action; } \\
\text { (e) A reasonable action to transfer or deploy the employee; } \\
\text { (f) A reasonable action to end the employee's employment by way } \\
\text { of redundancy or retrenchment; } \\
\text { (g) A reasonable action in relation to an action mentioned in } \\
\text { paragraphs (a) to (f); } \\
\text { (h) A reasonable action in relation to the employee's failure to } \\
\text { obtain a promotion, reclassification, transfer or benefit, or to } \\
\text { retain a benefit, in relation to the employee's employment. }\end{array}$ \\
\hline Reprisal & $\begin{array}{l}\text { The term 'reprisal' is defined under the Public Interest Disclosure } \\
\text { Act } 2010 \text { as causing, attempting to cause or conspiring to cause } \\
\text { detriment to another person in the belief that they or someone else: } \\
\text { - had made or intends to make a disclosure; or } \\
\text { - has been or intends to be involved in a proceeding under } \\
\text { the disclosure Act against any person. } \\
\text { Reprisal under the Public Interest Disclosure Act } 2010 \text { is a criminal } \\
\text { offence and investigations may be undertaken by the Queensland } \\
\text { Police Service. }\end{array}$ \\
\hline Subject officer & $\begin{array}{l}\text { An officer who is the subject of allegations of wrongdoing made in } \\
\text { a disclosure. }\end{array}$ \\
\hline Substantial and specific & $\begin{array}{l}\text { Substantial means 'of a significant or considerable degree'. It must } \\
\text { be more than trivial or minimal and have some weight or } \\
\text { importance. } \\
\text { Specific means "precise or particular". This refers to the conduct or } \\
\text { detriment that is able to be identified or particularised as opposed } \\
\text { to broad or general concerns or criticisms. }\end{array}$ \\
\hline
\end{tabular}




\section{Summary of the Public Interest Disclosure Process}

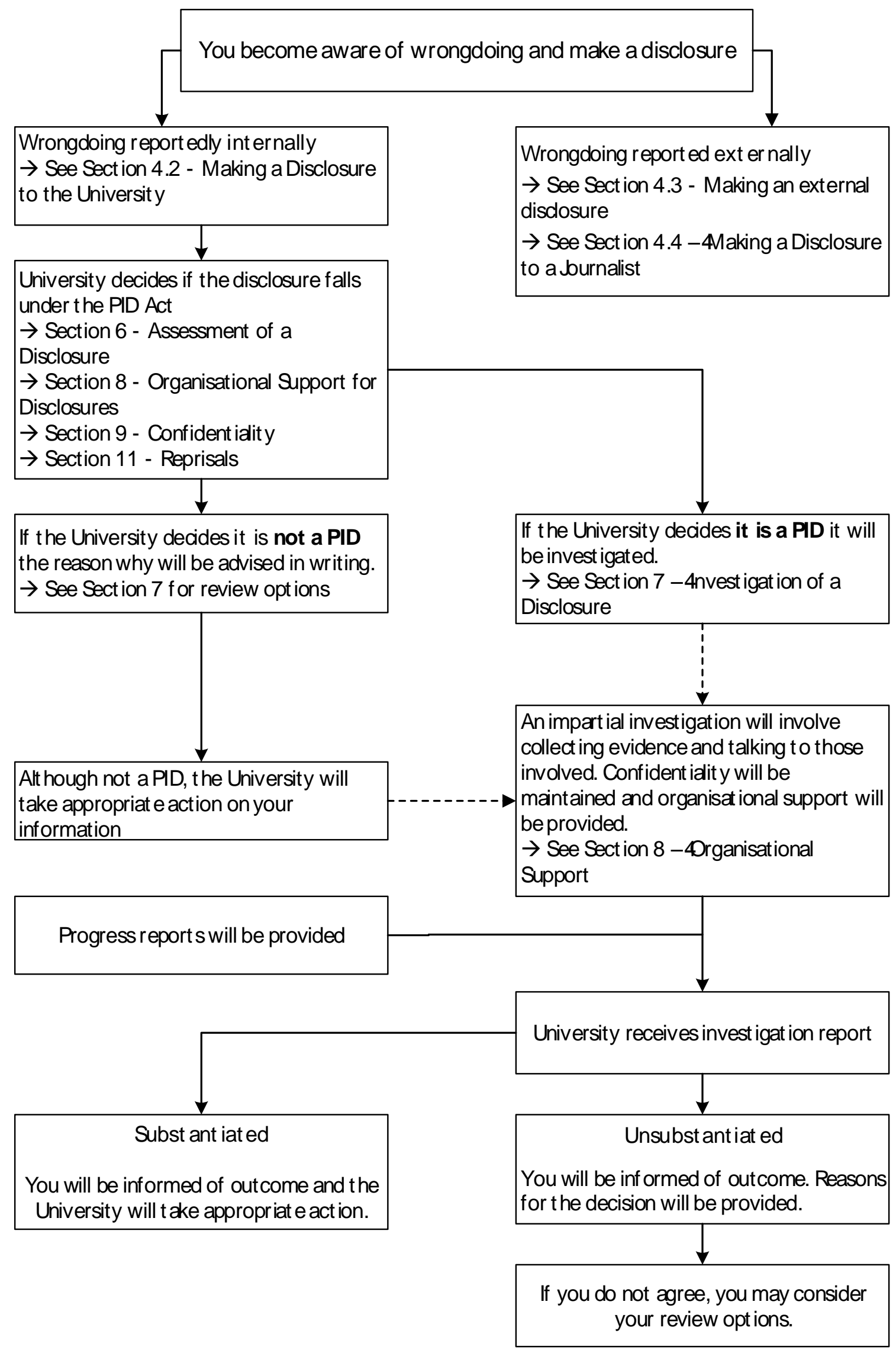


